\title{
北松型地すべりの写真判読とその問題点について
}

\author{
黒田和 男* . 岡重 文*
}

\section{On Some Problems Concerning the “Hokusho"-type \\ Landslides, based on Photogeologic Interpretation of the Landslide Topography}

\author{
by Kazuo Kuroda, Shigefumi Oka
}

\begin{abstract}
The Kitamatsuura Peninsura, northwestern corner of Kyushu, is a region in which landslides occur very frequently. Among them, the slub slides occurred in the Tertiary strata is called the "Hokusho"-type landslide, and is the most characteristic of the region. In this paper, the topographic feature caused by many landslides are discussed regarding their remote causes controlled by lithof acies and geological structure of the Tertiary system, distribution of talus deposits on the pediment-like slope, relief of the base of the Hachinokubo Gravel Bed and the Matsuura Basalts which unconformably cover the Tertiary system. The writer pointed out that the undulating topography on the gentle slope of the cuesta is caused by the slub slides in the Tertiary strata, which are composed of alternation of sandstone and aggregated layer of shale, tuffaceous shale, tuff and coal seams. Four examples, which occurred recently in the area, are described with accompanying photographs and diagrams.
\end{abstract}

九州北西部の北松浦半島には，多数の地すべり地形がみられる。筆者はこの地域の地すべり地形 を空中写真から摘出し，とくに地すべり地形と地質構造・崖錐層の分布等の関連を考察してみた。 地域内には，大規模地すべりの痕跡と思われる特有の地形が，第三系の構造と地形との関係からみ た場合のケスタの流れ盤のうえにあるといろ事をもとに，このような地形を作る要素は第三系の岩 質にあると予想した。特有の地形が形成されていく状況は, 現在も地すべり現象の中に観察でき る。ケスタの受け盤上の地すべりと緩斜面との関連性も, 空中写真上飞実際に観察された地すべり をむとに考察した。

な怙，地すべりの要因を第三系の岩質にあるとした場合，地すべり粘土が形成される過程にも若 干触れてみた。

\section{1. 緒 言}

九州北西端の北松浦半島から平戸島・生月島にかけ ての一帯は, 地すべりの頻発地帯として知られている 地域である。筆者のろち黒田は, 昭和37年以来数回に わたってこの地を訪れ，地すべりの実態とくに地すべ り地と地質との組合わせを観察して来た。また岡は, 昭和38年度飞, 現地踏査の結果と空中写真観察の結果 をもとに，地すべり地形の分布型態の図示を行なっ た。ここではその結果を発表するととあに，地質に関 する従来の調査研究成果をもとにした考察を加えて紹 介し，この地域の地すべり，とくに“北松型”と呼ば れている地すべり型式関する問題点を提供したい。

本稿を草すると当り, 長崎・佐賀両県下の地すべり

* 通産省地質誦査所

「写真测量」Vol. 6 No. 2
そ関する各種資料の提供を受けた長崎県庁・同県北開 発振興局・佐賀県庁関係各位に厚く感謝の意を表す る。

\section{2. 地質の概要}

この地域内に露出する地層・岩石は, 第三系に属す る杵島層群・相ノ浦層群・佐世保層群・野島層群执よ び平戸層，これらの第三系を著しい傾斜不整合で被覆 する八ノ久保砂礫層とその上飞乗る松浦玄武岩類で， 地域内の招もな河川に沿った小範囲に段丘堆積物拉よ び冲積層が僅かと分布している。また後述する崖錐堆 積物が広く分布している地域があり, 地すべり現象と はかなり密接な関連をもっている。

この地域の第三系には石炭を含む層準があるため， 古くから調査研究がことに第三系に対して行なわれて 来た。また玄武岩類も, その産状が本邦の中では特異 


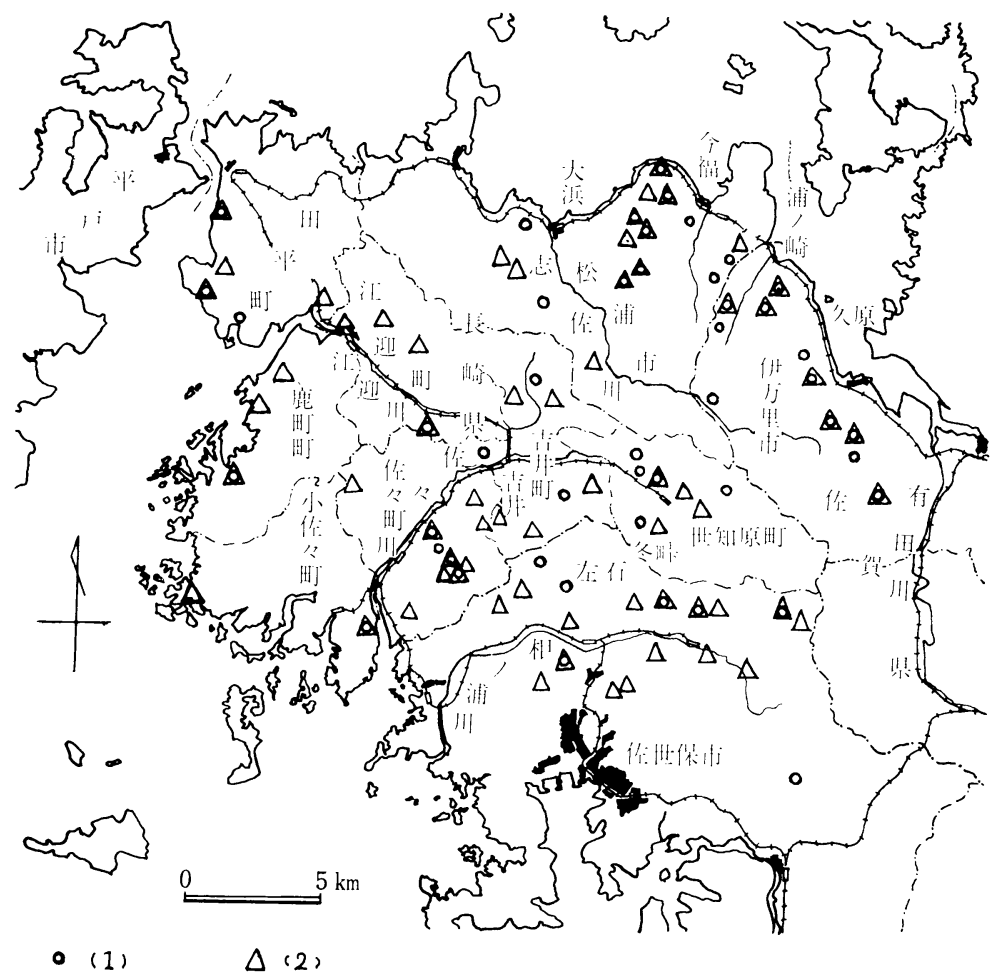

第 1 図研 究地域要 図

(1) 文献 32)，7）による地すべり地

(2) 地すべり指定地区

する臼ノ浦累層, しばし ば炭層・炭質頁岩をはさ む主砂岩・頁岩（末た は泥岩）の互層からなる 淡水成層—- 棚方累層, 多くの海棲貝化石を包蔵 する粗粒塊状砂岩 ・ 磞 岩・凝灰質岩が特徵的な 海成層である真申累層, 数枚の炭層をはさむ白色 砂岩がちの半跻半淡〜淡 水成層一一永ノ島累層飞 分けられる。臼ノ浦累層 を除いて，各累層中石 炭層を挾むが，炭層はし ばしば当時の火山活動を 示す火山砕屑岩を伴い, 炭層の生成と火山活動と は密接な関係があるとも 考えられる。永ノ島累層 最上位の炭層は大瀬五尺 と呼ばれ，この研究地域 の普遍的な炭層の 1 つで ある。

3) 佐世保層群：相ノ

なものであって，近年ことに注目されるようになっ た。これらの研究成果は数多く公表されているがその 詳細については他にゆずり，ここでは岩橋 (1962) に よってまとめられたものを要約して紹介する。
浦層群に引きつづいて堆積した砂岩・泥質岩と，それ らの互層からなる地層で，多くの稼行炭層を挾み，こ の地域の主琶夾炭層となっていると共飞，分布範囲も 広く“北松型”地すべりにもその主役となっている。
1）杵島層群：佐々川に沿って細長く 露出する本地域最下位の地層である。こ の層群は下位から杵島・曲川・三川内・ 早岐・大塔の 5 累層に分けられるが，こ の地域では三川内累層・早岐累層・大塔 累層がみられる。各累層は砂岩を主と し，それぞれ 1 つの堆積輪廻を構成す る。早岐累層の中部には, 凝扊質頁岩・ 粗粒凝灰岩・細砅岩の薄層・泥質細粒砂 岩ななどが互層をなしている部分があ る。顕著な石炭層はこの地域にはみられ ない。

2）相ノ浦層群：杵島層群にひきつづ いて堆積した地層で，大きくみて下位か ら, 白色塊状砂岩が優勢で, 閒飞数枚の 炭層をはさむ淡水〜半鲖半淡水成層-— 志田累層, 塊状砂岩・砂岩頁岩互層飞碟 岩・凝灰質岩などをはさむ海成層を主と

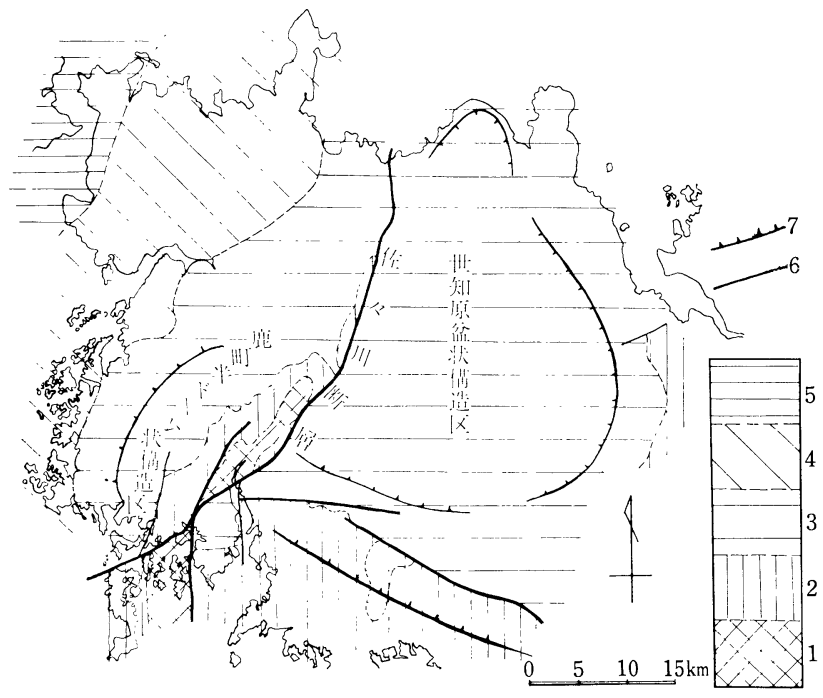

第 2 図 第三系の地質概要図

1. 杵島層群 2. 相八浦層群 3. 佐世保層群 4 野島層群

5. 平戸層の分布範囲 6. 断層 7 . 第三系の一般走向 
この層群は下位から，中里・下部柚ノ木・上部柚ノ 木・世知原・福井・加勢の 6 累層飞分けられ，それぞ れの累層のほぼ境界付近飞柚ノ木三枚・岩石二枚・ 松浦三尺・砂盤・福井一枚と呼ばれる炭層があって， 主要な稼行炭層となっている。岩石二枚の上方淿る 江里凝灰岩層はよく追跡されて東部地域と西部地域と の関係を明らかにする鍵となり，その他歌ケ浦凝灰角 砅岩層，本ケ浦凝灰岩層など顕著な火山砕屑岩層があ る。本層群は一般に半鹹半淡〜淡水成層の間にしばし ば海棲貝化石を含む比較的薄い海成層を不規則飞挾 み，また炭層と凝灰質岩石との関係は，相ノ浦層群の ようにかなり密接である。

6) 野島層群：地域北西部飞限って分布する砂岩・ 頁岩・砂岩頁岩互層・凝灰岩・凝灰角砂岩・礫岩から なる地層である。下位から大屋・深月・南田平の 3 累 層に分けられ，とくに大屋累層は佐世保層群に比較し てかなり多量の凝扊岩・凝死角礫岩括よび砅岩を含 み，激しい火山活動があったことを示している。

7）平戸層：野島層群のうえに不整合にのると考え られているやや固結度の低い優白色の砂岩·礫質砂岩. 砂質シルト岩の優勢な地質である。地域内では，北西 隅揤って分布する。

8）八ノ久保砂碟層：本研究地域のほとんど全域に わたって分布する砂礫を主とする地層である。第三系 との関係は著しい傾斜不整合である。砂礫層の礫は一 般によく円磨されている。凝灰質層や粘土質を挾むこ ともあり，層相・愿さともに水平方向連続しないこ と等から綜合して，三角州性堆積物とも瀕海性堆積物 とも考えられる。いずれにせよ，李だ解決していない 部分の多い地層である。

9）松浦玄武岩類：八ノ久保砂砅層を平行不整合に 覆ってこの地域を含む北西九州一带に広く分布し，広 大な熔岩台地を形成している。岩石は玄武岩で, 組織・ 構造・鉱物組成からさらと細分されている。熔岩の間 飞凝死岩・岩滓凝灰岩・凝灰角碩岩などの火山砕展 岩のほか，砂砅層や砂泥・粘土層を挾むことがある。

10）その他の第四系: 本研究地域の河岸段丘堆積物 は，潜龍付近飞著しいものがある以外，小規模のもの が認められる。また冲積層の分布も僅かである。崖錐 堆積物は，立武岩台地の周辺にみられ，区域によって はかなり広範囲第三系を覆って分布している。この 崖錐堆積物の分布状態を地すべり現象と関連させてみ た場合には，竹原 (1956) ・岩橋 (1962) の地質図で玄武 岩類として塗色されている部分の若干は, 岩屑層ある いは崖錐堆積物飞類するものとして取扱われねばなら ない。この点については後に記す。

\section{3. 地質構造の概要}

本研究地域の 地質構造は, 含 炭第三系と八ノ 久保砂砅層 - 松 浦玄武岩類とで は著しい差が認 められる。おず 第三系の構造 は, この地域中 央を北東一南 西飞斜断する佐 々川断層によっ て, 東側の世知 原盆状構造区 と, 西側の鹿町 半ドーム状構造 区と飞分けら れ，それぞれ次 のように区分さ れる。(第 2 図 参照)

\section{1）世知原盆} 状構造区

a) 国見山断

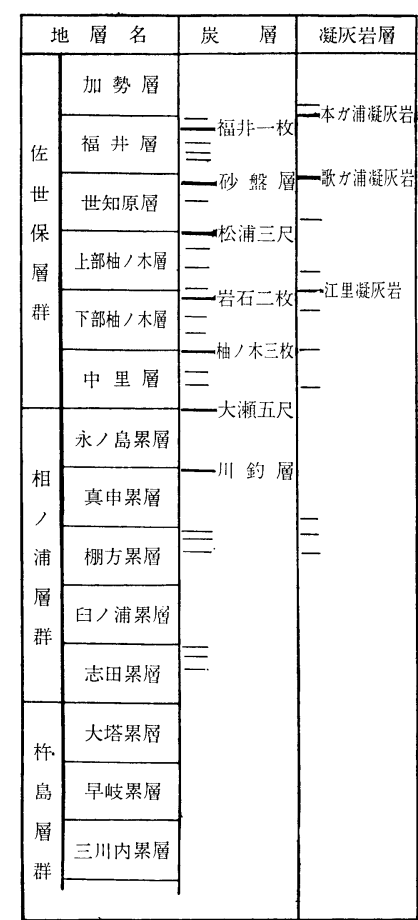

第 1 表 地層名と炭層 ・凝灰岩層との関係 な抢炭層名は地区によつて異なるので， ここでは標準と思われるものを通した。
層以北：一般々南北ないし北北東一南南西の走向が優 勢で，10内外で西方傾斜する。調川付近では北東 一南西汇走る向斜軸が認められ，その北西側では地層 は南東方へ 6 10 の角度で傾斜する。さらにこの向 斜軸の南東側江平行飞走るゆるやかな背斜構造が認め られる。断層は楠久断層を除いて大規模なるのは少な く，地層は非常飞安定している。

b) 国見山断層以南：全体として，ほぼ東西方向の

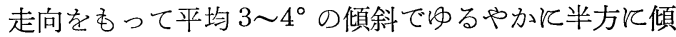
く单斜構造を示すが，佐々川断層に近接してこれに平 行飞走る非対称の向斜軸がある。また，地域東端の有 田川面する山腹では, 西飞向かう $20^{\circ}$ 以上の傾斜が 認められる。断層飞は, 芳ノ浦・賞観・泉福寺・針尾 断層その他が挙げられる。左石北方には，小断首の密 度の高い場所むあり, 小規模の盆状構造やドーム状構 造む認められるが，全体としては，安定した地塊であ るということができる。

\section{2) 鹿町半ドーム構造区}

a）佐々川断層地区：佐々川断層々，平野・志方・ 高崎の各断層にはさまれた地区で，小褶曲構造が認め られ地層の傾斜も $30^{\circ}$ 以上を示す場合がある。全体と して，佐々川断層の生成飞直接関係があるとみられる 擾乱帯である。 


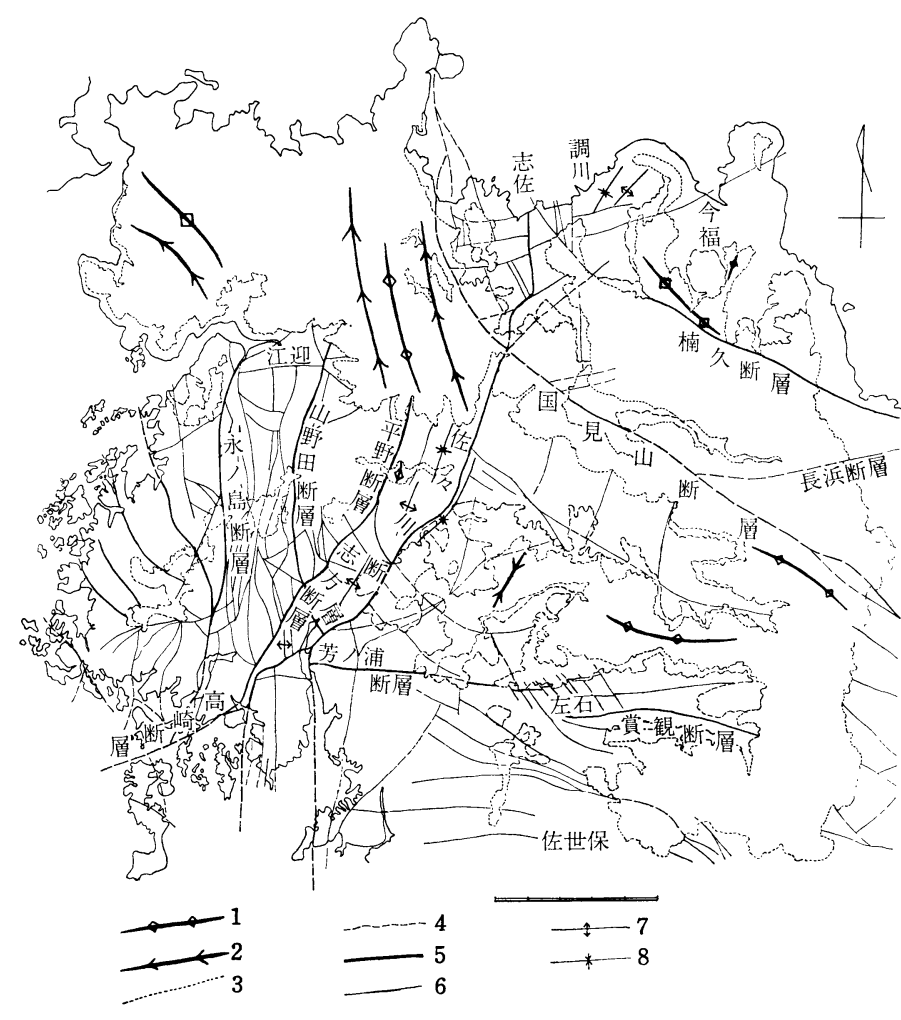

第 3 図 地質構造概念図

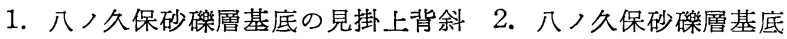
の見掛上向斜 3 . 松浦玄武岩・八ノ久保砂碩層の分布範囲

4. 崩積層の分布範囲 5 . 主要断層 6 . その他の断層 7 . 第 三系の背斜 8 . 第三系の向斜
かなドーム状構造や盆状構造があ る。佐々川断層·楠久断層·国見山断 層等の主要断層は，八ノ久保砂磞層 飞落差を与えている。以上のこと等 から，現在みられるこの砂磞層の起 伏は，必らずしも堆積開始当時の原 地形を表現しているとは言えず，そ の後の褶曲運動や断層運動の影響を 受けているとみなければならない。

沢田 (1956) は, 世知原盆状構造区 の第三系の基盤は，西彼杵半島の背 骨をなして広く露出する変成岩類 で, 有田以東の花崗岩類を基盤とす る伊万里微褶曲帯に比較し, 基盤が 若干沈降しているためと，第三系が 安定した構造を示していると考元， さら飞佐々川断首は北西方向からの 側圧が，かたい変成岩地塊飞第三账 を衝上させた結果出来たものである としている。しかし，第三系あるい は八ノ久保砂礘層・松浦玄武岩類の 構造㳘響を与えたものの考察は， 今後解決されるべき大きな問題とし て残された状況である。

\section{4. 地域内の地すべりに関 する従来の研究}

長崎県北松浦地方飞打ける地すべ b) 江里安定地区：平野・志方 - 山野田の 3 断層飞 かこまれる地区で断層も少なく, 地層の一般走向は東 西ないし東北東一西南西で, $3^{\circ} \sim 10^{\circ}$ の傾斜で北方に 傾くというきわめて安定した地区である。なお, 地区 の周辺部で, 上記の 3 断首に近接して, 若干の擾乱が みられる。

c) 盲目原断層地区：山野田・永ノ島両断層飞はさ まれた地区で, 無数の中〜小断首が網目状飞発達し, 全体として断層地带を形成している。地層は一般に北 西汇 $5^{\circ} \sim 25^{\circ}$ 傾斜している。

d) 鹿町·矢岳地区：永ノ島断首以西学ある鹿町半 ドーム構造区の主部で, 地層は一般に海岸に向かって $10^{\circ}$ 内外傾斜しているが，外側へ行くとしたがって， 傾斜注急飞なるといろ特性ももっている。断層は放射 状配列を示し, この構造区の特長となっている。

八ノ久保砂磞層の構造は, 巨視的飞みて $40^{\circ} \mathrm{E} の$ 走向で僅かに北西飞傾斜 (約 $\left.1^{\circ}\right)$ しいる。岩橋 (1961 a) は八ノ久保砂磞層基底の等高線図を描いてお りそのの見掛上背斜・向斜類する起伏が認めら れ, 第 3 図にその起伏状況を示して㧊いた。さらと僅
りの記載が始めてあらわれたのは, 経済審議庁 (1952) の調査結果で, こことは長崎県・佐賀県下合わせて15 箇所の地名が記されている。あるいは, それ以前の公 表された記録があるかも知れない。経済審議庁 (1952) そ引きつづいて, 長崎県下における地すべり調查結果 が報告され, 地すべり地あるいは地すべりの徵候が認 められる箇所が, かなり多数挙げられた。その報告書 の中で, 小貫 (1952) は, 県下の地すべりを, その地質 構成から次のようと分類した。

1） $\mathrm{A}$ 型: 第三系, 八ノ久保砂磞層, 松浦玄武岩類 が重なっている場合に，玄武岩の中を滲透する水の流 動飞伴なって立武岩の急斜面で割れ目が大になり, 遂 飞安定を失ってすべり落ちるものである。同時飞第三 系の岩石むすべり落ちることになるが, 簡単な場合飞 は砂礫層が押し出される程度である。この型は山くず れの要素もむっている。

2） B 型: 第三系のろえに玄武岩がのっている場合 飞, 第三系の岩石の上面飞粘土層が生じ, 岩石自体も 脆弱飞なっている。玄武岩中の割れ目飞沿って地下水 が流動する間飞亀裂が増大し, 安定を失って玄武岩が 
すべり落ちる。これむ山くずれの要素をむったもので ある。

3） C 型：第三系からなる山の急斜面には, 崩積層 (崖錐堆積物と記述したものと同じ意味)が堆積してい るが，玄武岩と第三系の岩石との境界位置から湧出す る極めて多量の水が地下水となって, 崩積層の中ある いは崩積層とその下の第三系との不整合面と沿って流 動し，その間に地すべりが起るもの。

4) D型：第三系の上飞は崩積層が厚く堆積してい る。第三系の上面怕，普通緩傾斜から急傾斜汇移って いるが，その上飞崩積層がある場合，傾斜変換部の上 飞乗っている崩積層の表面飞亀裂が生じ，地下水の流 動とよって崩積層がすべり落ちる。一たん滑動が始ま ると, あとは順次緩傾斜部の崩積層までその運動がお よんで行く。

5） $\mathrm{E}$ 型：第三系からなる岩盤の急傾斜面江，砂啋 層・崖錐層・崩積層がのっている場合飞, 地下水が殓 透して，岩盤の急斜面上飞のっている地層がすべり出 すむのである。移動する区域の上端・下端には刍裂が 形成されるが，区域の中央部には刍裂は少ない。

6） F 型：第三系の岩石には節理が発達している。 これと水が徐々飞渗透して頁岩は膨脹粘土化し， ある いは溶解して粘状となり，その結果地層の傾斜の方向 飞匍行が起る。

7） G 型：深度による陥没飞伴って山腹の傾斜側に 押出し移動する $\mathrm{a}$ 型と，採炭飞より地層の傾斜側飞陥 没亀裂を生じ，このため飞第三系の地層がその傾斜の 方向飞移動する b 型と飞分けられる。

以上， A・B 型は山くずれの要素を含み，主として 山地飞多く, C・D・E・F 型の地すべりは第三系の 分布地带飞多く，G 型は礦害に伴なう地すべりである とした。

岩塚 (1954) は, この地域の地形の特長として, 玄武 岩台地と現在の河谷底との間に山麓面様の緩傾斜面が あることに注目し, これを玄武岩流出後の侵食とより 形成されたあのであるとした。この緩傾斜面の上飞は 玄武岩岩原（崩積層・崖錐層と同じ）がのっている が，この玄武岩岩屑が移動するもの，第三系の風化し た表層も同時飞移動するすの，第三系の崩壊した物質 だけが移動するもの等の 4 つと分類した。

野田 (1957) は，この地域の地すべり・山くずれの特 長として，第三系とこれを不整合飞覆う砂磞層の上 に厚い玄武岩類がのり，山頂部は概して平坦で，その 台地状の山の縁は急傾斜で谷に面して扮り, 谷底には 第三系が露出しているという地形地質条件を挙げて, 柱状節理のよく発達した玄武岩およびその間に挾委れ る玄武岩質凝灰角砅岩，それ砂碩層がくずれやす $<$, 山腹の急斜面飞も崩土・岩屑・崖錐層が厚く堆積
してこれあまたくずれやすいことを示している。さら 飞上飞述べたすの以上飞基盤の第三系飞注目しなけれ ばならないとした。野田(1957)が「北松型」地すべり と命名したのは実にこれであって，第三系中にある頁 岩・石英粗面岩質凝灰岩ないし同質の凝灰岩質頁岩が 極めて上く粘土化されて㧍り，さら飞砂岩のブロック 化が著しいということが，第三紀層中の層すべり型地 すべりを起するととなり, 玄武岩や砂礫層, 崩土層な どをのせたまま岩盤が滑動するむのを指している。野 田(1957) 飞は，「北松型」と同時飞「東彼型」地すべり と命名したあのがあるが，両者は本質的に異なるあの ではないと筆者は考えている。

今井法か (1958) は，伊万里図幅地域内に属するこの 研究対象地域内で 17 箇所の地すべり地区を挙げてい る。地すべりの原因として，当地域の第三系は側圧に よる造構造運動をうけ,さらと著しい地塊運動を受け ていること，とくに有田川流域は伊万里微褶曲構造区 々世知原盆状構造区の境界飞当り, 有田川以西の地域 の第三系梳，莫大な量の玄武岩熔岩の重圧を受けてい ること等を考えているが，このことが直接地すべりの 発生飞結びつくものか否かは今後飞残された問題であ るとしている。

大島 (1965) は, 佐賀県内本研究地域の地すべりは, いわゆる第三紀層地すべりとして認識されているが， 必らずしも第三紀層飞主たる原因があるとは言えない とし，とくに第三紀層と地すべりとの関係について は,

1）頁岩飞とむ地層の分布地域に扬ける流れ盤型地 すべり

2)砂岩にとむ地層の分布地域で，断層飞近接した 地区の地すべり

の 2 つの型があることを示している。

黒田(1966)は, 本邦の地すべりを総括して, 堆積 性火山性・構造性の各地すべりと大別し，その中でか なり強く褶曲したりブロック化した古〜新第三系とき には白亜系から構成される地盤のうえに新しい火山岩 ないし礫層がのって大量の地下水の供給源となり,「円 弧状」怙よび「板状」すべりの双方があらわれる構造 性地すべりを「北松型」としたが，これも結局は小貫 (1952)の F 拈よび G 型であり，野田 (1957) の定義の 繰返しに過ぎない。

以上のよろに, この研究地域の地すべりの分類につ いては，ほぼ落着いたすのと思われるが，「北松型」と 呼ばれる第三紀層内部のすべりの現象が，岩盤内のど のような物理化学作用によって起るか等の問題の解明 は今後の課題であり，本文の目標もこの点としぼって 記述を試みている。 


\section{5. 地形と地質との関係}

本研究地域の地形で最す特徴があるのは, 玄武岩の 熔岩台地が広く発達していることである。その基底面 の高さは, 研究地域南東部飞扮いて最も高く, 全体と してゆるく北西傾斜して, 北西海岸では, その基底 面の高さは海水準以下となる。

この地域内を流れる扔むな河川とは，志佐川・江迎 川・佐々川・相ノ浦川があり，その他これ飞合流しあ るいは直接海に流れ込む小河川がある。これらの河川 は源流部を除いて，熔岩台地を削りその下の第三系の 中飞深く入り込えで流れ, 玄武岩の熔岩台地がこれら の谷飞面するところでは，100１50 m の高さの急斜 面が形成されている。また，第三系の中に谷がくい込 んでいる場合でも，たと光ば相ノ浦川支流の小川内川
飞沿っては, $150 \mathrm{~m}$ 飞近い急斜面が形成されている。

つぎそこの地形の特長として挙げられるのは, 山頂 から現河床面飞いたる間飞, 山麓緩斜面状の平坦地が 認められることである。この平坦地怰武岩だけの山 腹斜面飞認められる場合すあるが，とくに玄武岩台地 の周辺飞沿って発達し, 通常崖錐堆積物が乗ってお り，竹原 (1956) ·沢田 (1958) ·岩橋 (1961) (1962) の地質 図にもそれぞれ記入されているが，崖錐堆積物の分布 範囲は，それぞれ若干異としている。

岩塚（1954）は，玄武岩の崖と山麓緩斜面の境界位 置付近飞小平坦部が付着しているのを記述し，この平 坦部は玄武岩と第三系との不整合面の 1 部が侵食によ って玄武岩がはぎ取られた結果，再び地表現われた あのであるとした。これが成立するためには，第三系 からなる崖が後退するよりもはるか汇早い速さで玄武

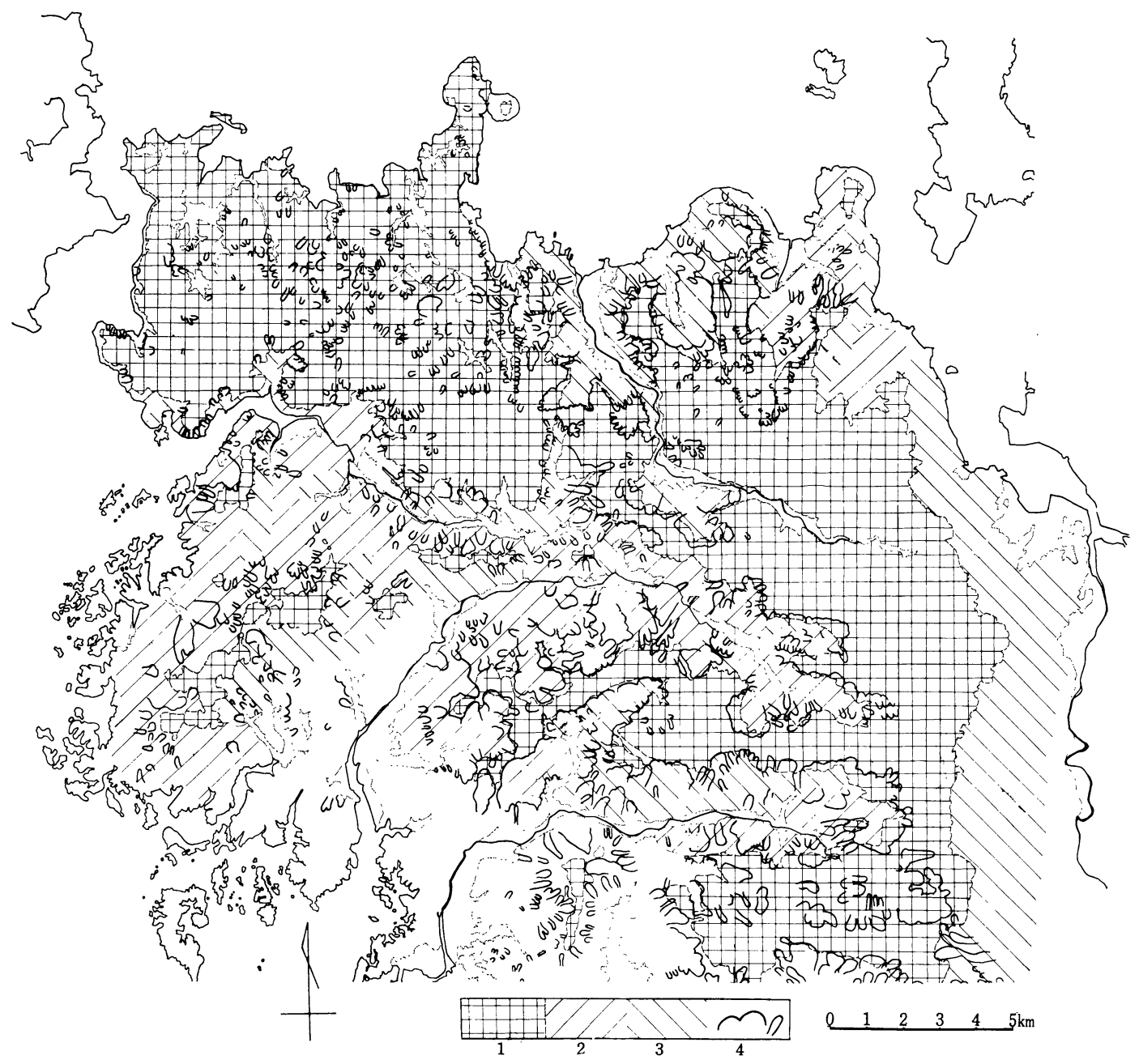

第 4 図地すべり地形分布図 使用空中写真 米軍撮影 M 102, M 665, M 742

1. 玄武岩類の分布範囲 2 . 流れ盤となる範囲 3 . 受け盤となる範図

4. 地すべりの滑落崖（写真判読による） 
岩の崖の後退が行なわれたものと考光 ねばならない。野田 (1957) も第三系に 属する岩石に比較して，玄武岩や砂碩 層がはるかとくずれやすい事を記して いる。

第 4 図は筆者の 1 人岡重文が, 現地 踏査の結果と空中写真観察の結果をも とに作成した地すべり地形の分布図で ある。この作業に使用した空中写真 は, 昭和 21 年から 22 年《かけて米軍が

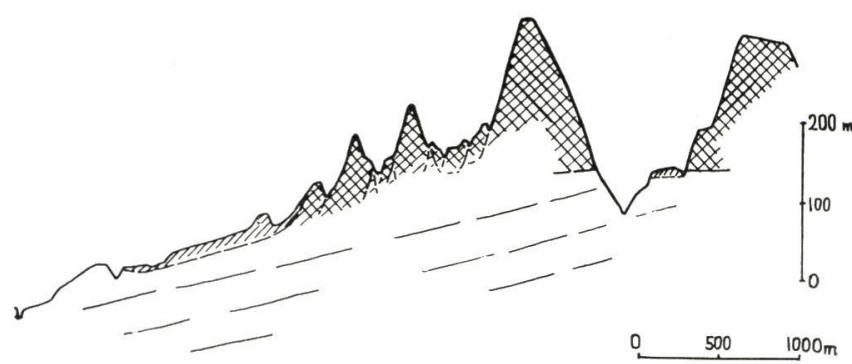
撮影した縮尺 4 万分の 1 のもの を使用している ため, その後に 発生した地す心゙ りがよく表現さ れていない。地 すべり活動によ って形成された とみられる馬蹄 型状の滑落崖そ の他の微細な地 表型態を求めた 結果を, 既存の 地質状況々対応 させてみると， この分布図では 小貫 (1952) 飞よ る $\mathrm{A} \sim \mathrm{E}$ 型の地 すべりないし山 くずれの痕跡が

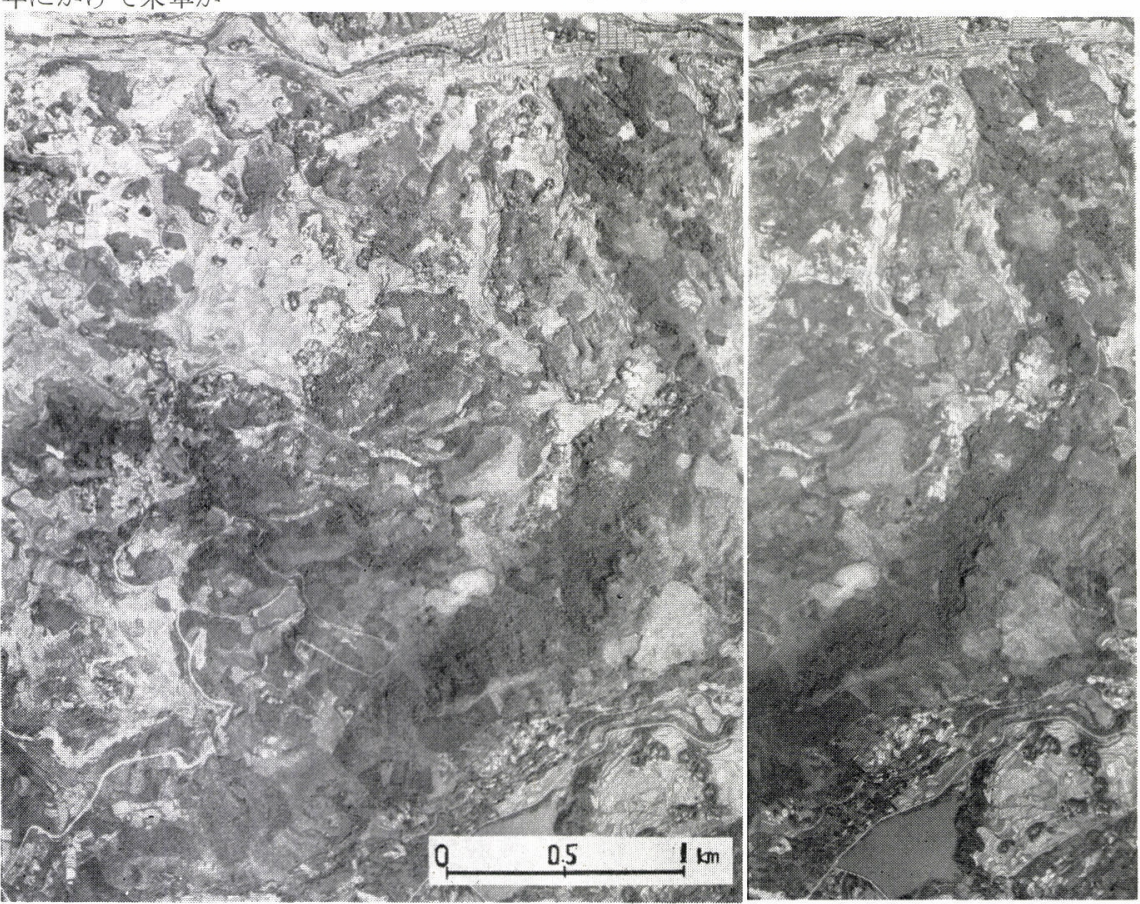

写真 1 吉井南東方の不斎地形

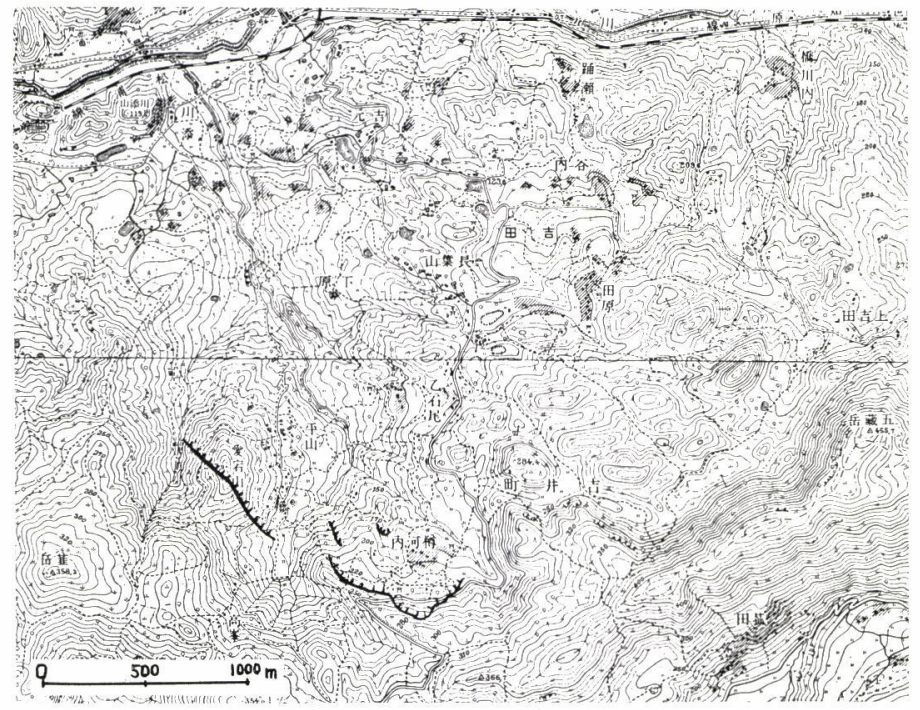

第 5 図吉井南東方の地形図

左側の亀裂線は, 平山地すべりの龟裂線
ほとんど大部分を占めている。そ ろして崖錐層の分布は $\mathrm{A} \sim \mathrm{E}$ 型の 地すべりに密接に関連しているこ とも，上図から了解されるが，吉 井南方・今福南方あるい注浦ノ崎 南方飞みられるような，広い山麓 緩斜面状の地貌を説明するには, まだ不充分である。最後に，この 山麓緩斜面を玄武岩の直下に分布 する第三系の構造上対応させてみ ると,もよりの河谷飞対して第三 系が流れ盤の関係になっている場 合は，受け盤の関係になっている 場合よりも山麓緩斜面の発達が著 しく，その極端な場合には，たと えば鹿町半ドーム構造区の場合, 玄武岩の分布はごく僅かで, 山麓 
緩斜面が玄武岩の山をとりまい て広く発達して打り, また研究 地域北東端一带では，玄武岩か らなる山の稜線はいちじるしく 東に偏して, ケスタ状の地形が 形成されて郝り，これは第 7 図 飞示すよう飞地質構造上から は,ケスタ地形そのものである。 そうしてケスタの流れ盤のうえ 飞“不斎地形”が認められる。 つぎにこの“不斎地形”の成因 を考察してみる。

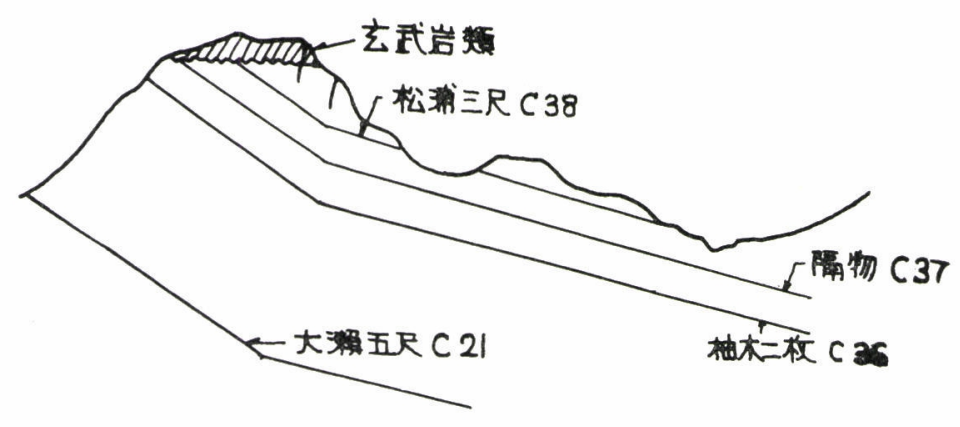

第 7 図 鷲尾岳地すべり地の模式地質断面図 記号は沢田 (1958) による炭層番号

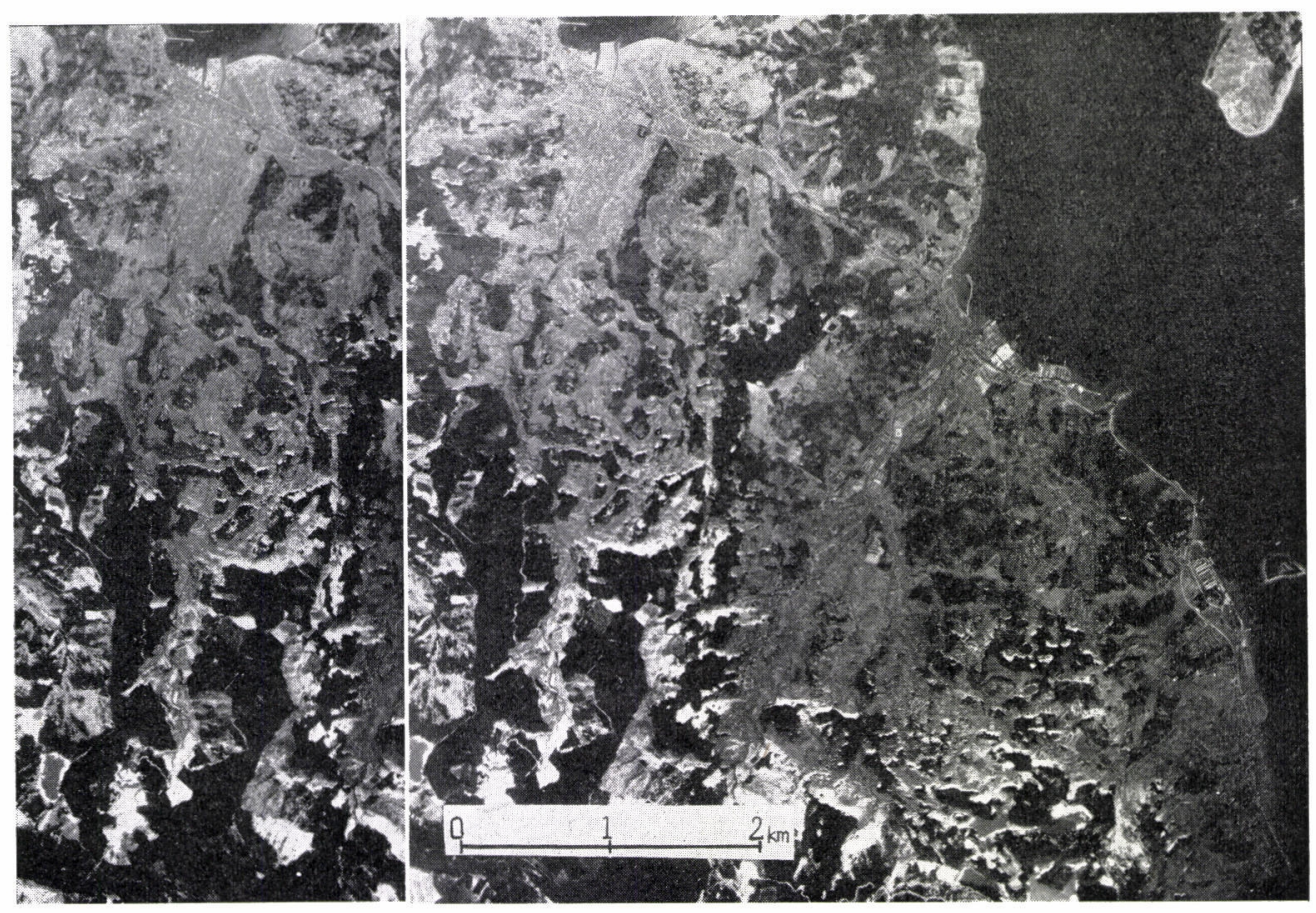

写真 2 今福南方の不斎地形

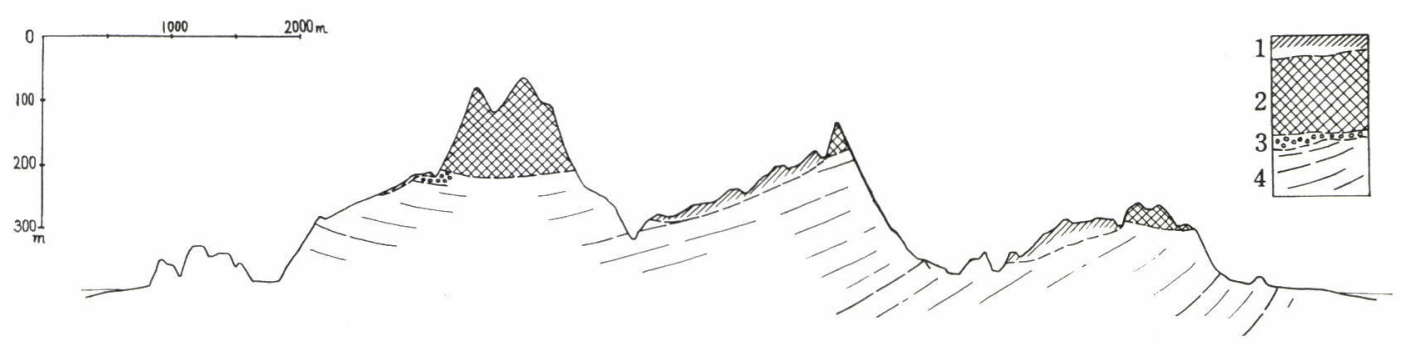

第 8 図 今福南方（大浜一久原間）地質推定断面図 凡例は第 6 図之共通

1. 崩積層または崖錐堆積物 2. 玄武岩類 3 . 八, 久保砂礫層 ( 1 部省略)

4. 第三系, 線は概略の層理面方向を示す。 

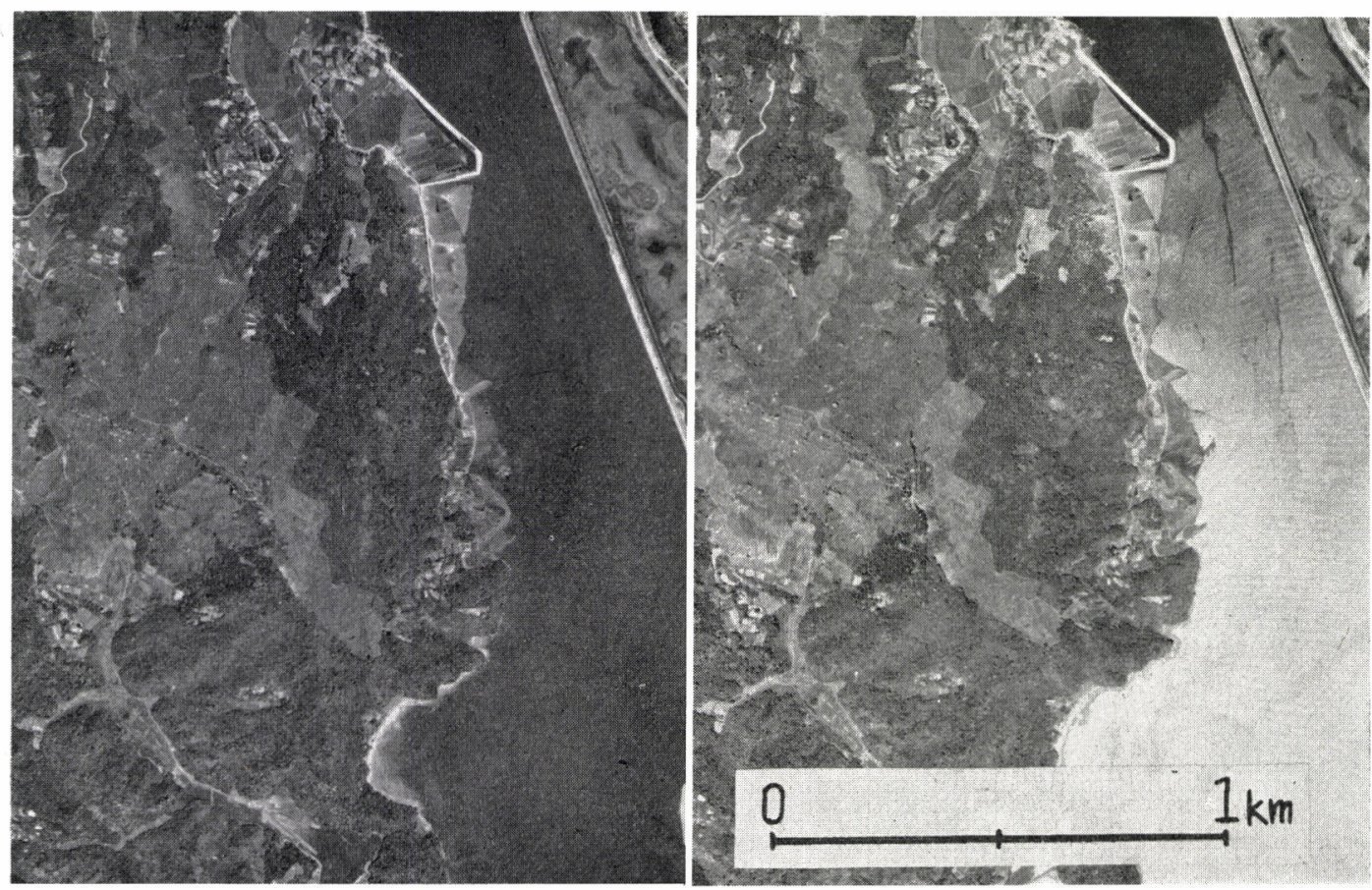

写真 3 大瀬 異 状地 形

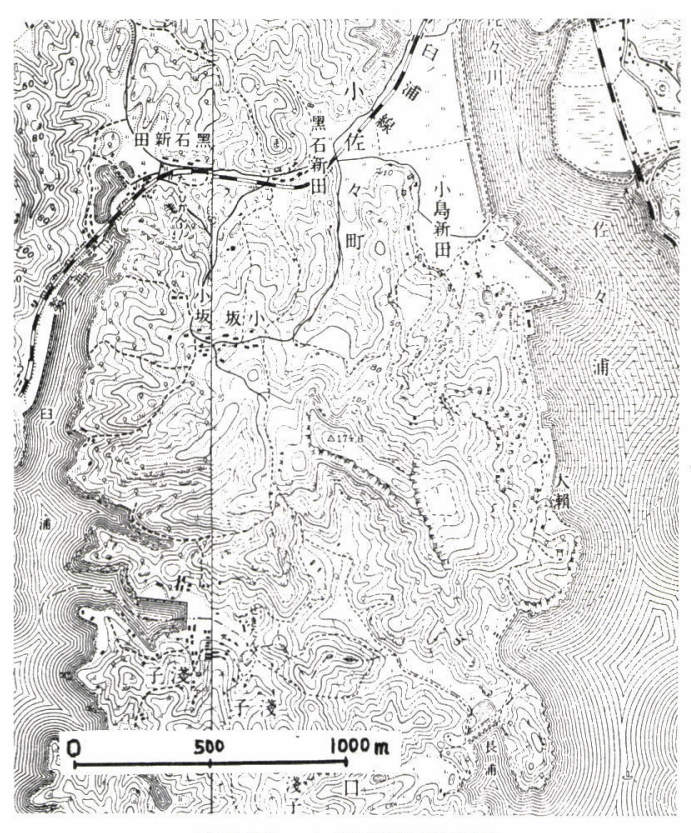

第 9 図大瀬付近地形図

\section{6. 地質的にみた地すべり現象の考察}

前項で述べたように, ケスタの流れ盤側にある山麓 緩斜面上には, 最大傾斜線の方向に直角に多数の小さ な丘が並び，丘の間には窪地が認められる場合があ る。このような地形は, 黒田(1963)がすでに指摘して いる。
上記の地形的特長活，大規模地すべり地形の特長と して古く中村 (1934)が記述したものと同じ型態をもっ ている。

黒田(1964) は, 能登半島基部のゆるく傾斜した砂 岩・泥岩・凝灰岩の互層からなる地域について, ケス 夕地形の地形発達史に地すべり活動が大きな影響を与 えていることを記述したが，その中でとくにケス夕の 流れ盤上飞発生する岩盤内の層すべりの痕跡が, 現在 の微細地形や水系網沅見られ，国見の大規模地すべり が, 今後どのようにケス夕地形に移るかという点に触 れてみた。ひきつづいて，国見の隣接地である胡桃 に, 凝灰岩をすべりの位置とする岩盤内の層すべりが 発生し, 頭部滑落崖や地すべり地塊内の“鬼ガ城”之 呼ばれる小丘が形成されるのが観察され, ケス夕地形 の発達と岩盤内の層すべりとの関係汶対する確証が得 られたものと思われる。

視野を拡げて, 日本で非常にゆるく傾斜した新第三 紀の砂岩・頁岩・凝灰岩の互層が分布する地域を眺め てみると，たとえば新潟県古志地方の中野俣のよう な, 過去に大規模な岩盤内層すべりが発生して形成さ れたと考えてもよい地形が諸所にみられる。

本研究地域では, 吉井町南方・今福南方・浦ノ崎南 方その他に同種の地形があり，これを地質構造や地盤 を構成する岩石の種類と対応させてみると, 完全に大 規模な層すべりの結果形成されたものと考えて差しつ かえない。 


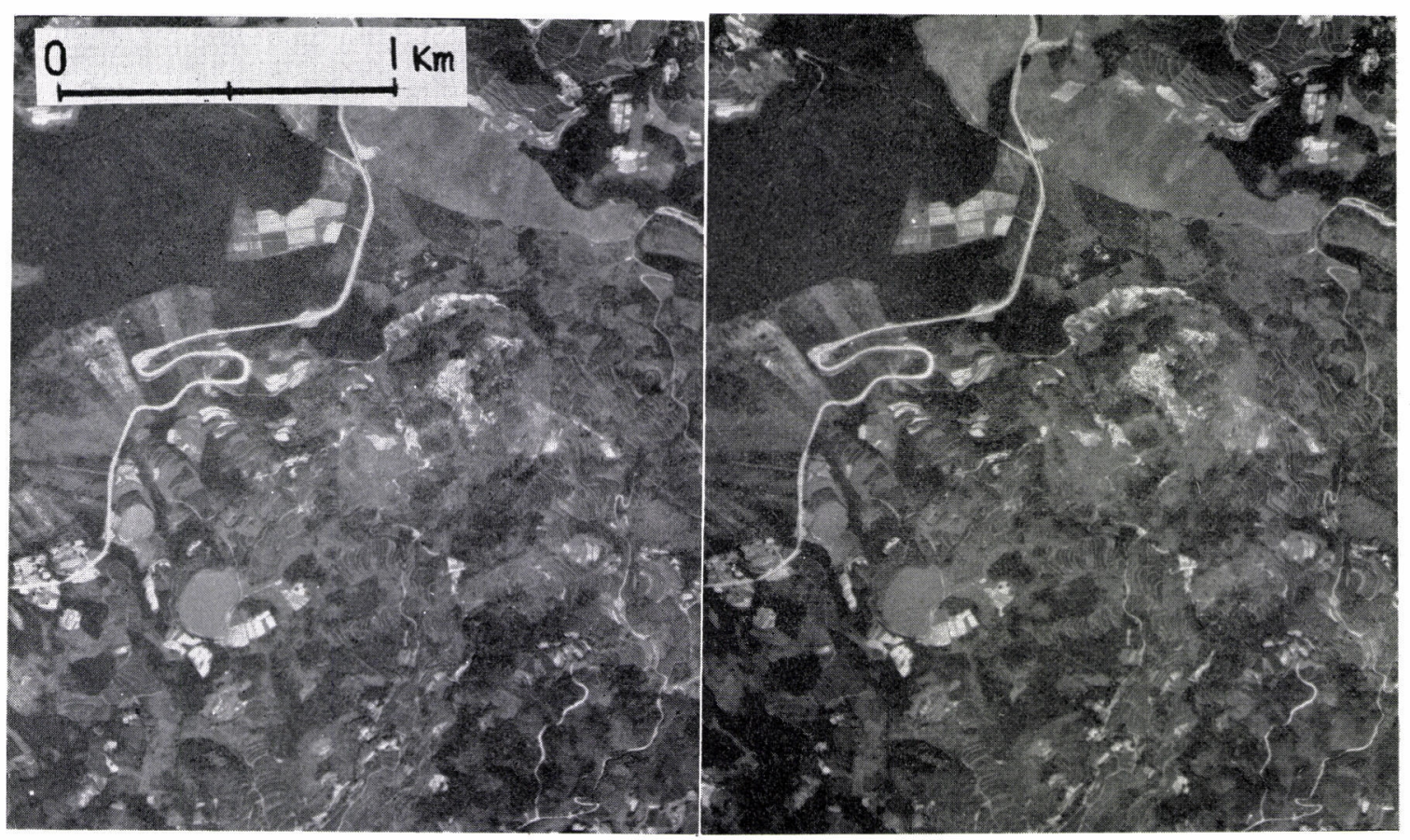

写真 4 冬拤南方の地すべり
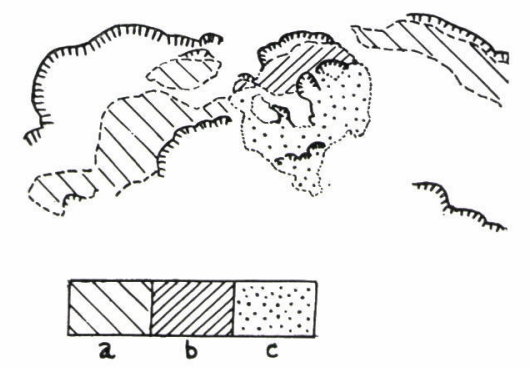

第 10 図

写真一 4 の説明 a. 古い緩斜面 b. 新 $5 し い$ 緩斜面 c. 地すべり被害地

吉井町南東方にみられる不斎地形は, 五蔵岳麓の高 さ $150 \mathrm{~m}$ の急斜面飞始末り, 緩斜面上飞高さ最大 70 $\mathrm{m}$ くらいの小丘や，〈ぼ地が並えでいる。等高線が楕 円形の閉曲線をなしている所では, その長径は東北東 一西南西方向と, 急斜面あるいは緩斜面の最大傾斜線 の方向と直角になっている。竹原 (1956) の地質図と, 岩橋 (1962) の地質図とで若干の相違があるが，この小 丘を構成している岩石は松浦立武岩類である。第 6 図 は, この不斎地形の断面図で, ケス夕の流れ盤の上に 松浦玄武岩類や崖錐層ないし崩積層がのっている状況 を示したもので，小丘の成因を“大規模”層すべりに よるものとして図示してあるが，実際に玄武岩類ある いは八ノ久保砂磁層の基底部が地質断面図上にどのよ

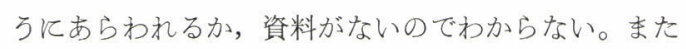

層すべり層準も, 今後の問題であろろ。

昭和38年 9 月頃から, 吉井町平山地内に発生した地 すべりは, その後急激な活動を示している。第 5 四に は, 最初の徴候として現われた龟裂の位置を示したも のであるが, 愛宕山はこの亀裂線を境として 2 つ割 れ, 北側のブロックが玄武岩や砂碟層をのせたま柰移 動して, 現在 (昭和 42 年始) は, 2 ついが出来上っ た。仮りにその移動が落着くとするならば, 数10年後 にあらわれる地形は, さきに述べた不斎地形内の小丘 と全く変りないものであると思われる。むし, この移 動が落着いたあとで小丘が急速に崩れて行くならげ, 緩斜面のうえに崖錐層が乗っているだけという形がで きる筈であるが, 眼前にとの変遷が見られないので, 単飞想像飞留めて打く。

江迎町鷲尾岳地すべりの場合は，亀裂が山の北斜面 にあるが, 移動の速さは平山地内のものに比較しては るかに遅い。この地すべりも層すべり型の地すべりが 実際観測された例である。な拉鷲尾岳地すべりの場合 のすべり層準は, 沢田 (1958) 方よるC 37 炭層 (現地 ではへダモノと呼えでいる) 付近にあるとされてい る。

今福南方・浦ノ崎南方の不斎地形の断面を描いてみ ると, 第三系の地質構造に対して, ケス夕地形の流れ 盤の上に乗っていることがわかる。ここでも, 閉曲線 となっている等高線は棈円形をなして呿り, その短軸 の方向が最大傾斜線の方向と一致している。写真 2 に 
挙げたものは，1月の降雪後の写真で，林地となって いる小丘と, 耕地となっている崩積層の部分とが明ら かに区別されるが，1/25,000 地形図のほうが，微細 な地形上の特徵をよく捕えている。浦ノ崎南方のケス 夕では, すべり層の層準は福井層の上限付近飞あると いってよい。な扮, 人形石山の崩壊は, このケスタの 受け盤側飞担当する。

小佐々町大瀬では， $1 / 25,000$ 地形図上飞露岩が記 されて扮り, 部落背後にも無数の散岩が記入されてい る。空中写真ではこの露岩のある所は滑落崖と判読 されるが，地区内に無数にあると期待される亀裂写 真上で求めることはできず，これは技そらく写真とし ての能力の限界であろろ。相ノ浦層群の露出する部分 と, 佐世保層群の露出する部分とでは, 細かい起伏模 様差がみられるがこれを熟尾岳の例と同じょうと佐 世保層群の下限付近をすべりの層準とみることが可能 である。現在は, 海岸飞沿って若干の変化が認められ るだけであるが，異状地形は明治 33 年測図の $1 / 25,000$ 地形図酒表現されていることから，非常飞古い時代 のものであるに違いない。この地すべり地形が原形を よく保っている理由としては，厚い砂岩層が侵食飞耐 える性質をもっているため，打よび上飞玄武岩類が乗 っていないために，渗透水の供給が僅かであることに よると思われる。

ケスタの受け盤側の地すべりは, 通常その規模が小 いためその他の理由むあって，岩盤内のすべりか表首 のすべりかの判定あ困難である。

冬峠南方の地すべりは, 空中写真でみる限り, 玄武岩 類と第三系の境界付近飞すべりの素因があるように思 われる。ここでは，地すべり運動とよって山麓階状の 緩斜面が新らしく形成している。仮りに地すべり地が このよろな状態で安定化し, 再び耕作や造林が行なわ れたならげ，新たと生じた緩斜面はいつまであ保存さ れ，逆地すべり岩塊が次々と破砕され風化され，順 次押し流されれば，斜面の下方飞崖錐層ないし崩積層 が形成されていく。このような目でみると，新らしい 地すべり地の両隣りとは, 高さを異飞した緩斜面と, その背後沿落崖を思わせる急緩面が並んで打り，乙 たがって緩斜面の形成飞関しては，岩塚(1954)の考兄 かたのあのがすべてであるとは言い切れない。ここに くわしい地質の調査が待たれる。

以上，北松型地すべりを現象としてとらえてみた が，その地質的な素因について，野田 (1957)は，石英 粗面岩質凝灰岩末たは凝灰質頁岩の粘土化飞あるとし ている。科学技術庁 (1963)は，岩盤内のすべりを起す ような岩盤内部の物理的末たは化学的变化はきわめて 徐々飞進行していると過ぎないと考えられ，岩盤の変 化を促進させる物質が降水を源とする滲透水であると
するならば，夾炭第三紀層の内部飞水がしみわたるよ ろな割れ目の集中している筒所があるとしている。泊 (1965) は, この研究地域の膨脹性頁岩飞ついて報告し ているが，とくに世知原層の最下部（松浦三尺層の直 上）飞発達する有孔虫含有の黒色〜暗褐色頁岩層が非 常に良く脹膨する事を記述している。

岩橋 (1962) は, 本研究地域の石炭の石炭化作用を促 したものとして, 根源植物の相違・生物化学的段階で の变質・物理化学的変質段階での変質・地質構造・火 成岩や温泉熱の影響を挙げ，それぞれの場合を細かく 吟味して, 結局炭層の被覆岩の厚さが最む石炭化度飞 影響を与えたと考元，さら飞鹿町半ドーム構造区のド 一ム中心付近地下飞火成岩体の存在が予想されるの屯 無視できないとしている。本地域の石炭層と凝灰岩層 とは密接関連していることは前に述べたが，凝灰岩 層の粘土化に上記のような影響も考慮しなければなら ない。

池田 (1964)などの観察によれば，第三系の砂岩・泥 岩互層中の地下水は，1つの層準飞沿ってかなり離れ た距離を流動することが示されている。また熔岩流・ 凝灰角碚岩等は極めて水を含みやすく，岩盤中の割れ 目飞対して水タンクの役目を果している。このような 事例を総合してみると，ケスタ地形の形成は首すべり 型地すべりの結果であり, 北松型地すべりは, この地 域の地形発達の 1 つの過程であるとしてよい。

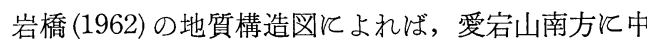
心をあつ局部的なドーム構造がある。ドーム構造の中 心部は開いた割れ目が出来やすい条件にあると言って よいが，この構造が現在す生成しつつあるあのかどう かは，地すべり現象の素因を考察するのに見逃しては ならないと思われる。

\section{7. 結 び}

北松浦半島飞抢ける地すべり現象に関係した地形 を，地質との関連のもと飞考察してみた。しかし，地 質・地質構造・岩質氏コントロールされた地形を考察 する場合飞は，基礎となる地質構造が充分把握された あのでなければならない。この研究地域では, 玄武岩 が地表を覆っているために，その下に伏在する第三系 の地質構造を把握するのは容易でなく，本文で資料と した岩橋 (1962) の総括地質図についても，まだ検討し なければならない問題点がある。そこで今後の問題と して,

1. 玄武岩飞覆われた地域の, 伏在第三系の地質構 造の再検討

2. 山麓緩斜面の中には, ケス夕地形の性質をるつ ものああり，末た玄武岩流出後の海岸段丘など侵 食地形面もあるかす知れ妨が，その区別が因難で 
ある。この差を地質構造ともとづいて明らかにす ることが挙げられる。

\section{参 考 交 献}

1）芥川真知・金子幸子(1966)：空中写真による地 すべり地形の判読，土木研報告, 117, 115 131.

2) 地質調查所 (1959)：20万分の 1 地質図幅「唐津」

3) 地質調查所 (1960)：日本糖産誌 V-a （主として 然料となる鉣石

4) 地質調查所 (1965)：20万分の 1 地質図幅「長崎」

5) 波多江信広 - 有吉正夫 - 由代信夫 (1961)：佐世 保炭田志佐川上流地域の地質, 特飞加勢層の異 常発達について, 九州鉱山誌, 29, 4, 167 178.

6)池田俊雄 (1964): 国鉄新幹線弁天山トンネル内 の地質と湧水について，応用地質，5，2，71～80.

7) 今井 功・沢村孝之助 - 吉田 尚 (1958)：5 万 分の 1 地質図幅「伊万里」及同説明書, 地質摆査 所.

8) 岩橋 徹 (1960)：長崎県北松浦郡九十九島 - 佐 々地区の杵島層群の層序之地質構造—“佐世保 炭田” の研究 (その 1), 九大理研報 (地澌学), 5,1 , $1 \sim 13$.

9) 岩橋 徹 (1961a)：北松地域およびその周辺に みられる八ノ久保砂碟㬝 (新称) について一“佐 世保炭田”の研究 (その 2), 九大理研報 (地質学), $5,2,80 \sim 97$.

10）岩橋 徹 (1961 b)：佐世保炭田飞分布する相， 浦層群の綜括的層序 - 岩相変化 ・堆積状況につ いて一“佐世保孷田”の研究 (その3), 九大理研 報(地啠学), $5,111 \sim 1288$.

11) Iwahashi, T. (1961 c) : Study of the Sasebo coal field, northwestern Kyushu, Japan. Part 1, Stratigraphy of the Tertiary Sasebo group, Mem. Fac. Sci., Kyushu Univ., Ser. D, Geo$\log \mathrm{y}, 11,3,419 \sim 439$.

12) 岩橋 徹 (1962)：“佐世保炭田” 炭の石炭化度 の地質学的研究, 九大理研報(地質学), 6, 2, 95 134.

13) 岩塚守公 (1994)：長崎県北部の地过りとその一 般的特性飞ついて, 地理学評論, $27,6,244 \sim 254$.

14) 科学技術庁研究調整局 (1963)：北九工地域地す ベり山くずれ等調査一昭和 38 年度防災科学推進費によ る現地調查報告書

15）経済審議庁計画部国土調查課 (1952)：全国地过 り地の概要

16) 小林 勇・今井 功・松井和典 (1952)：5 万分 1 の地質図幅「唐津」及同説明書, 地質調査所.

17）小出 博 (1955)：日本の地之り, 東洋経済新報社.

18）小出 博ほか 5 名 (1963): 地すべり地飞生き る，実業公報社.

19）黑田和男 (1963)：山くずれの予知, 地質ニュース, 104, 22 29.

20）黑田和男 (1964)：能登半島基部地すべり地帯の 地形発達について，地すべり, $1,2,9 \sim 18$.

21）黒田和男 (1966)：地すべり地と地質構造の因果 関係について, 地学雑誌, 75, 3, 123 135.
22) 黒田和男・白井慶治・吉川惠也 (1963)：国鉄新 幹線由比ずい道の地質とその応用地質学的解釈 応用地質, 4, 3, 150 155.

23) 長浜春夫 (1963)：長崎県北松浦郡平戸島付近の 地質, 地娚月報, $3,11,583 \sim 586$.

24）長浜春夫 (1953)：佐世保炭田に関する若干の新 事実と考察，地質月報，4，1，63 67.

25）長浜春夫(1954)：佐世保炭田飞招けるいわゆる 佐世保層群上部について, 地質月報, 5, 8, 413 440.

26) 長浜春夫 - 松井和典 (1958)：5 万分の 1 地質図 幅「蠣, 浦」及问説明書, 地質謂查所.

27）長浜春夫 (1962)：佐世保㬝群中上部に打ける崖 酋・炭層の上・下盤の等層厚線図括よび鍵層間 の等層厚線図について, 地瀳月報, 13, 11, 67 70.

28) Nagahama, H. (1964): Relation between the Azimuths of Diagonal Bedding Pattern and Isopach Map Pattern on the Fukui Formation of the Sasebo Coal Field, Nagasaki Prefecture, Jour. Geol. Soc. Japan, 70, 827, 500 507.

29）長浜春夫 (1965)：斜層理からみた北西九州第三 紀層の堆積，地質謂査所報告, 211 , 地質調查所.

30) 中村慶三郎 (1934)：山崩, 古今書院.

31）中村慶三郎 (1955)：崩災と国土一地之り山崩の 研究, 古今書院

32) 長崎県地之対策本部 (1952)：長崎県の地沪り.

33）長崎県農業試験場 (1960)：20万分の 1 長崎県地 質図.

34) 野田光雄 (1952)：長崎県北松浦郡地过り予想地 調查報告, 長崎県の地之り, 3 14.

35）野田光雄 (1957)：唐津佐世保崗孷田内の地过り そついて，九州鉱山誌，25, 11, 443 452.

36）小貫義男(1952)：長崎県北部地方の地之り飞就 て，長崎県の地之り，67〜207.

37) 大島恒彥(1965)：佐賀県下地江り地区の地質学 的背景, 第 2 回災害科学総合講演会講演論文，95 98.

38）佐賀県 (1954)：5 万分の 1 佐賀県炭田地質図.

39）沢村孝之助 (1952)：北松田地帯の玄武岩と断層 (演旨), 地質学雑誌, $58,682,308$.

40)沢田秀穗(1956)：佐々川衝動に関する若干の覚 書, 地筫月報, $7,1,29 \sim 32$.

41）沢田秀穂(1958)：北松炭田地質図及同説明書, 日本炭田図 II, 地質調查所.

42) 沢田秀穗ほか 3 名 (1955)：5 万分の 1 地質図幅 「平戸」及同説明書, 地質調査所.

43）高野秀夫 (1960)：地すべりと防止工法, 地球出版,

44) 竹原平一 (1956)：佐世保炭田の層序学的研究 $($ その $\mathrm{I} \sim \mathbb{N})$ ，九州鉱山誌，24，8，411 428，9，492 506, 11, 573 587, 12, 607 611.

45) 泊 正雄 (1965)：筑豊・佐世保・福岡炭田の一 部の膨脹性頁岩, 九州鉱山誌, 33, 3, 98 114.

46) 平上誠喜 (1959)：熟尾岳地区地すべり対策工事 そついて, 地之研究, 第3輯, $25 \sim 45$.

その他地点に関するものは省略した。 